\title{
小型チャンバーにおける気流速度と水蒸気換算物質伝達率との関係 MASS TRANSFER COEFFICIENT IN SMALL CHAMBER WITH AIR FLOW CONTROL UNIT
}

\author{
金勲*, 田辺新一** \\ Hoon KIM and Shin-ichi TANABE
}

\begin{abstract}
Using the newly developed airflow control unit (ACU), chamber performance was examined through measuring the air velocity $\left(\mathrm{v}_{\mathrm{a}}\right)$ near the specimen surface and mass transfer coefficient (MTC). $v_{a}$ and its distribution depending on fan revolutions were examined over nine points at a distance of $10 \mathrm{~mm}$ from the specimen surface. MTC was investigated by tests with using filter papers and water vapor in the chamber installed with ACU. For MTC tests, seven conditions of fan revolution were set at less than 700rpm, and loading factor 0.11 $\mathrm{m}^{2} / \mathrm{m}^{3}$ was adopted to avoid saturating of humidity in the chamber instead of $2.2 \mathrm{~m}^{2} / \mathrm{m}^{3}$ of usual emission test. As the results, $v_{a}$ distributions were even and in a small deviation. When $\mathrm{v}_{\mathrm{a}}$ ranges from 0.10 to $0.27 \mathrm{~m} / \mathrm{s}$, tested MTC were in 17.4 to $22.0 \mathrm{~m} / \mathrm{h}$, while the values of JIS and previous studies in much lower levels. Chamber-tested MTCs should be much lower than those of theoretical calculation, because the given Q/A would make the potential of mass transfer decreased at the chamber test but theoretical calculation have the assumption of infinite $\mathrm{Q}$. There, theoretical MTC depending on $\mathrm{v}_{\mathrm{a}}$ were recalculated using the properties of dry and wet air. CFD simulations provided that steady state appeared at over $\mathrm{L}=0.44 \mathrm{~m}^{2} / \mathrm{m}^{3}$ at $\mathrm{v}_{\mathrm{a}}=0.1 \mathrm{~m} / \mathrm{s}$ and the MCT was $15.3 \mathrm{~m} / \mathrm{h}$, which was close to the result of the chamber test at $300 \mathrm{rpm}$ (much less than $0.1 \mathrm{~m} / \mathrm{s}$ ), because the limited ventilation rate in the chamber test restrained the vapor transfer and consequently MTC. It was cleared that tested MTC always showed the higher values than JIS and theoretical ones, and could become close to other ones by compensation considering the velocity boundary layer and the loading factor.
\end{abstract}

Keywords : Mass transfer coefficient, Air Velocity, Loading Factor, Air flow control, Small chamber 物質伝達率，気流速度，試料負荷率，気流制御，小型チャンバー

\section{1.はじめに}

建材からの化学物質放散測定のためのチャンバー法はチャンバー 内に清浄空気を供給して換気を行いながら放散量を測定するため、室 内に設置された建材の周辺環境により近い条件下で試験を行うこと ができる。国内では、建材から放散される化学物質の放散量測定に JIS A 1901 「小形チャンバー法」注1)1 に準拠した 20L 小型チャンバー が多く使われている。

建材から放散される化学物質は建材内部から表面に拡散移動し、表 面から周辺空気に移動してゆく。放散物質の建材表面から周辺空気一 の移動しやすさを物質伝達率 ${ }^{2}$ と表し、JIS A 1901 では水蒸気換算物 質伝達率 9 18m/h（気流速度 0.1 0.3 m/s 相当）を推奨している。チャ ンバー法の国際規格である ISO 16000-93) では水蒸気換算物質伝達率 ではなく、試料表面から $10 \mathrm{~mm}$ 離れた地点における気流速度として $0.1 \sim 0.3 \mathrm{~m} / \mathrm{s}$ を定義している。

20L 小型チャンバーを用いた放散試験では通常、換気回数 0.5 回 $/ \mathrm{h}$ を採用しており、その際チャンバー内で気流制御を行わない場合は $4 \mathrm{~m} / \mathrm{h}$ 以下 ${ }^{4)}$ 5) 6) と報告されている。 JIS では水蒸気換算物質伝達率を確 保することを推奨しているが実験方法は示されていない。

一方、吸着分解性能を持つ機能性建材の開発と使用が増加している ことから、低減建材の濃度低減性能を評価する JIS A 1905（2007 年 2

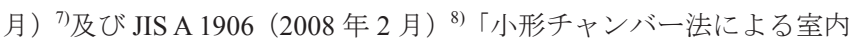
空気污染濃度低減材の低減性能試験法－JIS A 1905 ; ホルムアルデヒ ド、JIS A 1906 ; ホルムアルデヒドを除いたカルボニル化合物及び VOCs」が制定された。

吸着建材は気中の污染物質分子が建材表面に衝突・吸着されて効果 が現れるもので、濃度低減性能は空気分子と建材表面との接触率、寸 なわち濃度境界層性状に大きく影響を受ける。そのため、JIS A 1905 ・ 1906 では JIS A 1901「小形チャンバー法」より厳格な物質伝達率範囲 を定めている。20L 小型チャンバーにおいてもより均一な表面気流性 状及び信頼性高い物質伝達率の制御が必要となる。

物質伝達率の違いが吸着建材の濃度低減性能に与える比較試験は 安宅・加藤ら ${ }^{9)}$ にって報告されている。また、朱・加藤ら $\left.{ }^{10}\right)$ は実験 と CFD (Computational Fluid Dynamics) 解析を通じ、デカン・トルエ ンなど 5 種類の VOC に対して境界層型小形 Test Chamber を用いた気 流速度と物質伝達率との関係を調べている。

水蒸気換算物質伝達率に関しては村上・加藤・伊藤ら $\left.{ }^{4)} 11\right)$ 、田辺・ 田中ら ${ }^{6)}{ }^{12}$ によって報告されているが、試料表面付近における実際の 気流速度と物質伝達率との相関を調心゙た研究は行われていない。

\footnotetext{
* 早稲田大学理工学術院理工学研究所

学術院講師 ·博士 (工学)

** 早稲田大学理工学術院建築学科 教授.工博
}

Lecturer, Department of Architecture, Waseda University, Dr. Eng.

Prof., Department of Architecture, Waseda University, Dr. Eng. 


\section{2. 研究背景と目的}

チャンバーの放散試験においては物質伝達率が重要である。薄膜を 形成する塗布材は蒸散支配型材料と呼ばれ、物質伝達率に放散速度が 受ける影響は大きいが、合板、MDF、ボード類などの内部拡散支配 型材料は建材内部での物質移動抵抗が大きいため、材料表面の物質伝 達率に影響される度合いは大きくない。しかし、気中の化学物質を吸 着して気中濃度を低減させる吸着低減建材に関しては材料表面と空 気中の化学物質分子の接触確率によって吸着効率 (低減性能) が変化 するため、物質伝達率が重要な変数となる。

そのため JIS A 1905/1906「吸着低減性能試験法」では $15 \pm 3 \mathrm{~m} / \mathrm{h}$ (気 流速度換算 $0.25 \pm 0.05 \mathrm{~m} / \mathrm{s}$ 相当）と JIS A 1901 の放散試験法より厳格 な物質伝達率範囲を定めている。

既往研究によると、気流制御を行わない 20L 小型チャンバーに対

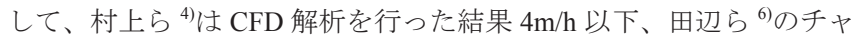
ンバー試験結果からは $3.1 〜 4.7 \mathrm{~m} / \mathrm{h}$ とされている。また、境界層型チ ヤンバーを用いた伊藤ら ${ }^{11)}$ の研究ではチャンバー中心位置（試料表 面から $30 \mathrm{~mm}$ 離隔）における気流速度 $0.1 \mathrm{~m} / \mathrm{s}$ 時に $15.7 \mathrm{~m} / \mathrm{h}$ 、水平型気 流制御ユニットを用いた田中ら ${ }^{12)}$ の試験では推定気流速度 $0.2 \mathrm{~m} / \mathrm{s}$ で 15.2 16.0m/h を報告している。Zhang らの整流型チャンバーを用い た水面からの蒸発量測定試験 ${ }^{13)}$ では、水面温度を測定していないた め推定ではあるが、 $25 \mathrm{~mm}$ 離隔点における気流速度 $0.1 \mathrm{~m} / \mathrm{s}$ で物質伝達 率 $9.7 \sim 10.7 \mathrm{~m} / \mathrm{h}$ と算定される。

JIS で定める物質伝達率を制御し、推奨範囲を満足させるためには 気流制御用補助器具を導入する必要があり、その際には試料表面全体 に均一な気流分布を形成することも重要である。そのため、筆者らは 20L 小型チャンバー内の試料表面に均一な気流条件を形成させると 共に物質伝達率の制御ができる縦型気流制御ユニット (以下、ユニッ ト）を開発・改良してきた ${ }^{14)}{ }^{15)}$ 。

本研究では気流速度及び試料負荷率と物質伝達率との関係を明ら かにすることを目的とした。具体的には気流制御ユニット使用時の試 料表面気流速度測定及び水蒸気を用いた物質伝達率試験を行い、物質 伝達性能を調べた。また、水蒸気を用いた物質伝達率試験では試料負 荷率によっては相対湿度が $100 \%$ RH に近くなるため試料負荷率を低 下させた。しかし、同じ空間容積と換気量に対して試料負荷率が低く なると物質放散ポテンシャルが高くなり、実際のチャンバー試験条件 とは異なることが考えられたため、CFD を用いた数值解析を通じ、 試験值と気流速度から算定した理論值及び数值解析結果を比較検討 した。

\section{3. 気流制御ユニット}

本研究で用いた縦型気流制御ユニットの写真及び概要図を図 1 に 示す。20L チャンバー内に設置できる程度のユニット大きさでは気流 経路が短く整流気流を作ることが難しい。チャンバー内に攪拌ファン のみを設置しても物質伝達率を変えることはできるが、試料表面周辺 の気流分布を一様にすることが難しい。新型ユニットでは吸引式ファ ンを使用し、また気流通過経路を複数回曲げることでファンによる気 流の直接的な影響を少なくすると共に緩衝部（気流経路）を長くする ことで試料表面周辺に整流に近い気流が形成できるようにした。また、 ユニット上部 (空気導入部)には金属製のメッシュが設けられている。 ユニット下部には SUS とテフロン製で作られたファンが設置され、
ユニットの側面にシールボックス 2 個（試料負荷率 $\mathrm{L}=2.2 \mathrm{~m}^{2} / \mathrm{m}^{3}$; 以 下本文中で単位省略）を装着し、チャンバーに投入する。シールボッ クスに設置された試料の表面はユニット内で形成される一定な気流 に曝露される。
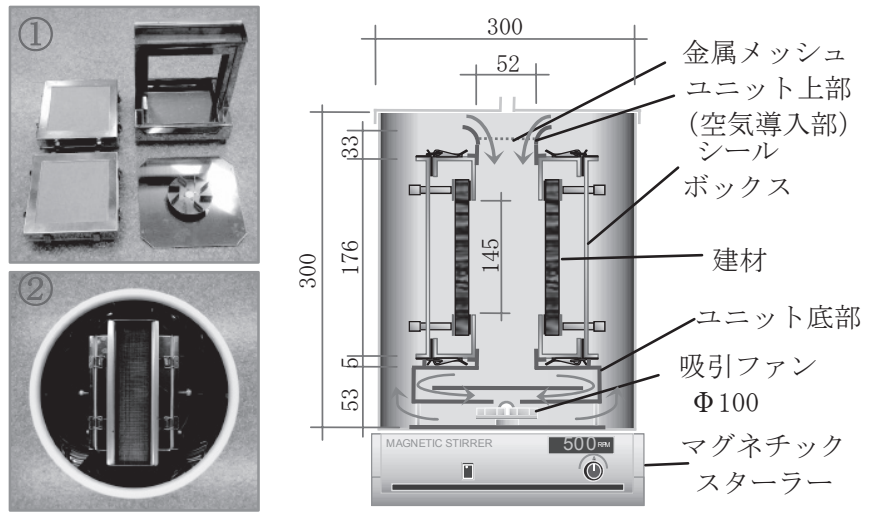

写真(1) : シールボックス、ユニットフレーム、吸引ファン 写真(2) : 組立てたユニットのチャンバー内設置風景

図 1 縦型気流制御ユニット

\section{4. 試料表面付近の気流速度測定試験}

\section{1 実験概要}

気流速度測定点及び気流速度測定風景を図 2 に、気流速度測定の試 験条件を表 1 に示す。ユニットにシールボックスを装着し、アクリル 製の $20 \mathrm{~L}$ 可視化チャンバーに投入した。気流速度はユニットに装着 されたファンをマグネティックスターラーの回転数を調節すること で制御した。スターラー回転数とファン回転数のずれに関しては非接 触型デジタル回転計（RM2000、カスタム社）を用いて測定し、殆ど 誤差がないことを確認した。気流速度測定には白金素子風速計

(SIBATA ISA90、0.05m/s $22.99 \mathrm{~m} / \mathrm{s}$ で表示分解能 $0.01 \mathrm{~m} / \mathrm{s})$ を用いた。 試料はユニットの両側に設置できるがチャンバー及びユニットの形 状は左右対称であることから片側のみの測定とした。試料表面を 9 領域に分割して、気流速度は試料表面から $10 \mathrm{~mm}$ の位置において 60 秒間平均值を測定した。9 点測定を 1 測定周期とし、同一回転数条件

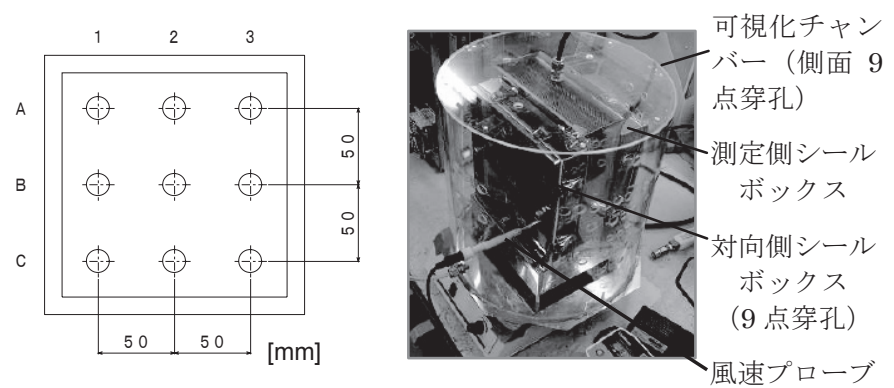

図 2 気流速度測定点及び測定試験風景

表 1 気流速度測定試験 試験条件

\begin{tabular}{c|l}
\hline チャンバー & アクリル製 $20 \mathrm{~L}$ 可視化チャンバー \\
\hline 換気量 & $167 \mathrm{ml} / \mathrm{min}(0.5$ 回 $/ \mathrm{h})$ \\
\hline 温湿度 & 成り行き \\
\hline 測定ポイント & 3 点 $\times 3$ 点 $($ 縦 $\times$ 横 $)$ \\
\hline 気流速度測定位置 & 試料表面から $10 \mathrm{~mm}$ 離隔 \\
\hline ファン回転数 & $450 \cdot 500 \cdot 600 \cdot 700 \mathrm{rpm}$ \\
\hline 測定間隔 & 60 秒間平均風速 $(\mathrm{n}=3)$ \\
\hline 風速計 & SIBATA 微風速計 ISA90
\end{tabular}


にて 3 周期測定を原則とした。但し、測定值が $0.1 \mathrm{~m} / \mathrm{s}$ より大きく下 回る条件若しくは $0.3 \mathrm{~m} / \mathrm{s}$ を大きく上回る条件では 1 回測定とした。

\section{2 実験結果}

測定結果から得られたファン回転数と面平均気流速度との関係を を図 3 に、9 点における気流速度分布（各点平均值）を表 2 に示す。 回転数と気流速度には正の直線による相関が見られた。9 点におけ る表面付近気流速度偏差は回転数 450、500、600、700rpm 条件にお いて RSD\%は 13、11、7、8\%となった。低い回転数条件において標 準偏差が大きくなったが、これは微風速での計測精度のためである。 面平均気流速度は、回転数 $450 \mathrm{rpm}$ で気流速度 $0.10 \mathrm{~m} / \mathrm{s} 、 700 \mathrm{rpm}$ で 0.27m/s であり、ISO16000-9 及び JIS A 1901 で指定する気流速度を満 足するには 450〜 725rpm、JIS A 1905/1906 を満足するには 580〜 $725 \mathrm{rpm}$ が必要となる。気流速度 $0.1 \sim 0.3 \mathrm{~m} / \mathrm{s}$ における Re 数（計算式 及び物性值条件は「5.1 物質伝達率」参照）は732２195 となる。以 上の結果からユニットは気流速度分布の少ない均一な表面気流を形 成することができると考えられる。

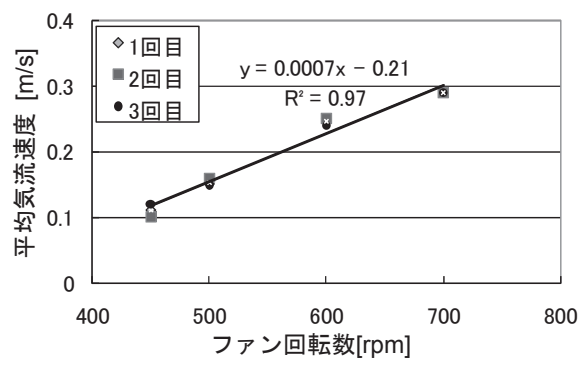

図 3 ファン回転数と面平均気流速度

表 29 点における気流速度分布（3 回測定の平均值） $[\mathrm{m} / \mathrm{s}]$

\begin{tabular}{|c|c|c|c|c|c|c|}
\hline 条 件 & \multicolumn{3}{|c|}{$450 \mathrm{rpm}$} & \multicolumn{3}{|c|}{$500 \mathrm{rpm}$} \\
\hline 測定点 & 1 & 2 & 3 & 1 & 2 & 3 \\
\hline A & 0.11 & 0.12 & 0.09 & 0.16 & 0.16 & 0.12 \\
\hline B & 0.11 & 0.11 & 0.09 & 0.15 & 0.15 & 0.12 \\
\hline C & 0.09 & 0.11 & 0.09 & 0.13 & 0.15 & 0.13 \\
\hline 条 件 & \multicolumn{3}{|c|}{ 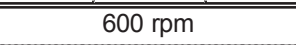 } & \multicolumn{3}{|c|}{$700 \mathrm{rpm}$} \\
\hline 測定点 & 1 & 2 & 3 & 1 & 2 & 3 \\
\hline$A$ & 0.25 & 0.23 & 0.22 & 0.30 & 0.30 & 0.26 \\
\hline B & 0.22 & 0.25 & 0.22 & 0.26 & 0.29 & 0.26 \\
\hline C & 0.22 & 0.23 & 0.23 & 0.25 & 0.28 & 0.25 \\
\hline
\end{tabular}

\section{5. 物質伝達率測定試験}

\section{1 物質伝達率}

物質伝達率は以下の式（1）～（3）から算出する ${ }^{2) 6 。}$

$$
\begin{aligned}
& k_{x}=k_{c} \times \rho \\
& M_{\text {evp }}=A \times k_{x} \times\left(x_{w}-x_{a}\right)
\end{aligned}
$$

$A \quad:$ 試料面積 $\left[\mathrm{m}^{2}\right]$

$M_{\text {evp }}$ : 蒸発量 $[\mathrm{kg} / \mathrm{h}]$

$k_{c} \quad$ : 蒸気濃度基準物質伝達率 $[\mathrm{m} / \mathrm{h}]$

$k_{x}$ : 絶対湿度基準物質伝達率 $\left[\mathrm{kg} / \mathrm{m}^{2} \mathrm{~h}(\mathrm{~kg} / \mathrm{kg}(\mathrm{DA}))\right]$

$x_{a} \quad$ : 雰囲気空気の絶対湿度 $[\mathrm{kg} / \mathrm{kg}(\mathrm{DA})]$

$x_{w}$ : 濾紙表面温度と等しい温度の飽和空気の絶対湿度 $[\mathrm{kg} / \mathrm{kg}(\mathrm{DA})]$

$\rho$ : 空気の密度 $\left[\mathrm{kg}(\mathrm{DA}) / \mathrm{m}^{3}\right]$

蒸発量 $M_{\text {evp }}$ は、チャンバーの出口空気・入口空気の絶対湿度差から 式（3）により求めることができる。

$$
M_{\text {evp }}=\frac{Q \times\left(x_{\text {out }}-x_{\text {in }}\right)}{v}
$$

$Q$ : 換気量 $\left[\mathrm{m}^{3} / \mathrm{h}\right]$

$v \quad:$ 比容積 $\left[\mathrm{m}^{3} / \mathrm{kg}(\mathrm{DA})\right]$

$x_{i n}$ : チャンバー入口空気の絶対湿度 $[\mathrm{kg} / \mathrm{kg}(\mathrm{DA})]$

$x_{\text {out }}$ : チャンバー出口空気の絶対湿度 $[\mathrm{kg} / \mathrm{kg}(\mathrm{DA})]$

水蒸気物質伝達率及び周辺空気の気流速度の関係を推定すること が可能である。以下の式 (4) 〜 (7) により、無次元数のシュミット 数 $(S c)$ 、シャーウッド数 $(S h) 、$ 、イノルズ数 $(R e)$ を求め、濾紙表 面付近の気流速度を推定する。拡散係数及び動粘性係数は物質伝達率 試験結果、チャンバー内空気温湿度が $29^{\circ} \mathrm{C} 、 80 \% \mathrm{RH}$ 前後となったた めその温湿度条件における值を用いることとした。

$$
\begin{aligned}
& S c=\frac{v}{D} \quad \ldots(4) \quad S h=\frac{k_{c} \times l}{D} \\
& R e=\frac{u \times l}{v} \quad \ldots \text { (6) } \quad S h=0.664 \times R e^{1 / 2} \times S c^{1 / 3}
\end{aligned}
$$

$D$ : 水蒸気の拡散係数 $\left[\mathrm{m}^{2} / \mathrm{h}\right]\left(29^{\circ} \mathrm{C} 、 1 \mathrm{~atm}\right.$ の時は $\left.0.095 \mathrm{~m}^{2} / \mathrm{h}\right)$

$S c$ ：シュミット数 [-] Sh ：シャーウッド数 [-]

$R e ：$ レイノルズ数 $[-] \quad u$ : 風速 $[\mathrm{m} / \mathrm{h}]$

$l \quad:$ 代表長さ $[\mathrm{m}]$ （試料長さ $0.147 \mathrm{~m}$ を用いた）

$v$ : 動粘性係数 $\left[\mathrm{m}^{2} / \mathrm{h}\right]\left(29^{\circ} \mathrm{C} 、 80 \% \mathrm{RH}\right.$ 湿り空気 $\left.3.64 \times 10^{-2} \mathrm{~m}^{2} / \mathrm{h}\right)$

\section{2 試験概要}

表 3 に物質伝達率試験条件を、図 4 に物質伝達率測定試験風景を示 す。試験対象物質としては蒸留水（水蒸気）を、放散基材として濾紙 (第 2 種)を用いた。

表 3 物質伝達率測定試験条件

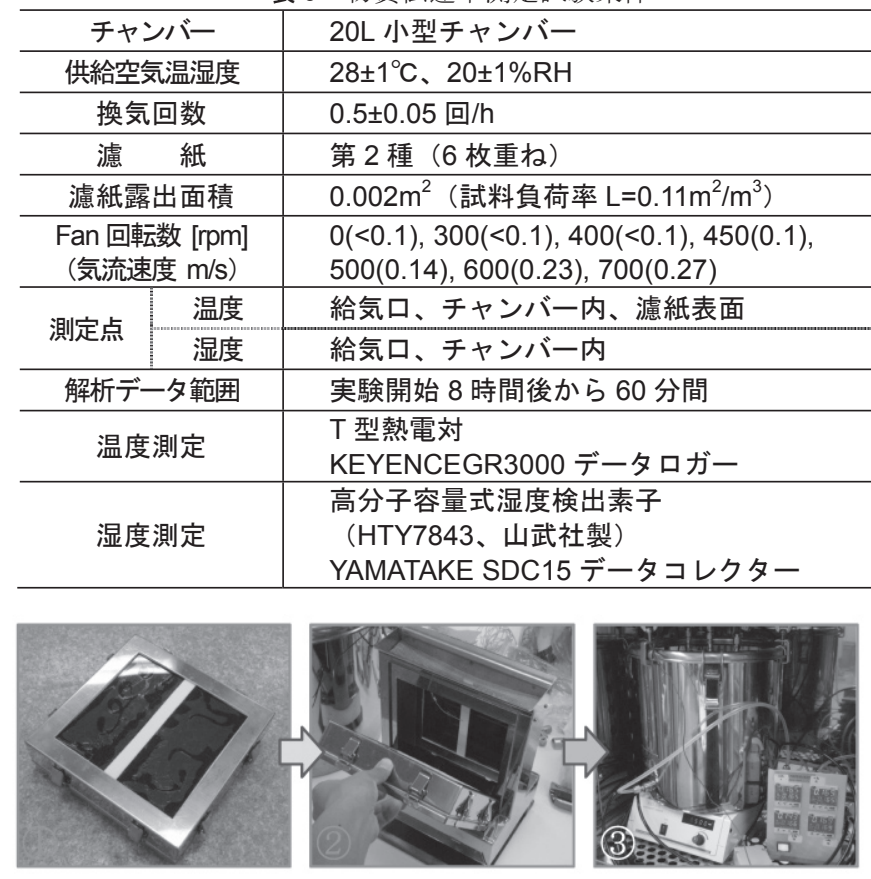

写真(1) : 蒸留水に含浸させた濾紙 6 枚を重礼て設置。試料面積 $147 \mathrm{~mm} \times 147 \mathrm{~mm}$ のうち $1 / 10$ は濾紙、残りは樹脂製プレートとなる。

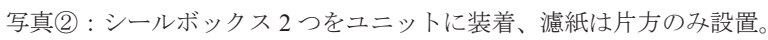

写真(3) : マグネティックスターラーの上にチャンバーを設置。

図 4 物質伝達率測定試験風景 
表 4 物質伝達率試験測定結果

\begin{tabular}{|c|c|c|c|c|c|c|c|c|c|c|c|}
\hline \multirow{2}{*}{ 項目 } & \multirow{2}{*}{ 気流速度 } & \multicolumn{2}{|c|}{ 給気 } & \multicolumn{3}{|c|}{ 排気 } & \multicolumn{2}{|c|}{ 濾紙表面 } & \multirow{2}{*}{ 蒸発量 } & \multirow{2}{*}{ 密度 } & \multirow{2}{*}{$\begin{array}{l}\text { 物質 } \\
\text { 伝達率 }\end{array}$} \\
\hline & & 温度 & 絶対湿度 & 温度 & 相対湿度 & 絶対湿度 & 温度 & 絶対湿度 & & & \\
\hline 単位 & {$[\mathrm{m} / \mathrm{s}]$} & ${ }^{\circ} \mathrm{C}$ & $\mathrm{g} / \mathrm{kg}(\mathrm{DA})$ & ${ }^{\circ} \mathrm{C}$ & $\% \mathrm{RH}$ & $\mathrm{g} / \mathrm{kg}(\mathrm{DA})$ & ${ }^{\circ} \mathrm{C}$ & $g / k g(D A)$ & $\mathrm{g} / \mathrm{h}$ & $\mathrm{kg}(\mathrm{DA}) / \mathrm{m}^{3}$ & $\mathrm{~m} / \mathrm{h}$ \\
\hline $0 \mathrm{rpm}$ & - & 28.3 & 4.74 & 27.5 & 71.7 & 16.52 & 26.0 & 21.37 & 0.135 & 1.175 & 11.5 \\
\hline $300 \mathrm{rpm}$ & - & 27.9 & 4.63 & 29.1 & 75.0 & 19.01 & 27.7 & 23.64 & 0.163 & 1.169 & 14.6 \\
\hline 400rpm & - & 28.3 & 4.73 & 28.9 & 76.7 & 19.27 & 27.5 & 23.24 & 0.165 & 1.169 & 17.3 \\
\hline 450rpm & 0.10 & 27.8 & 4.68 & 29.1 & 76.6 & 19.45 & 27.6 & 23.46 & 0.168 & 1.169 & 17.4 \\
\hline 500rpm(1) & \multirow{2}{*}{0.14} & 28.3 & 4.73 & 29.1 & 77.3 & 19.61 & 27.4 & 23.15 & 0.169 & 1.169 & 19.8* \\
\hline 500rpm(2) & & 27.8 & 4.61 & 29.1 & 76.8 & 19.56 & 27.7 & 23.60 & 0.169 & 1.169 & $17.4 *$ \\
\hline 550rpm & - & 28.0 & 4.65 & 29.3 & 77.4 & 19.91 & 27.8 & 23.66 & 0.173 & 1.168 & 19.2 \\
\hline $600 \mathrm{rpm}$ & 0.23 & 28.4 & 4.77 & 29.1 & 78.1 & 19.85 & 27.5 & 23.31 & 0.171 & 1.169 & 20.5 \\
\hline $700 \mathrm{rpm}$ & 0.27 & 28.3 & 4.74 & 29.0 & 79.3 & 20.07 & 27.5 & 23.36 & 0.174 & 1.169 & 22.0 \\
\hline
\end{tabular}

※ 500rpm 条件については、2 回試験の平均值 $18.6 \mathrm{~m} / \mathrm{h}$ を用いた。

0.5 回/hのチャンバー内が安定するまでは少なくとも $5 \sim 8$ 時間以上 かかることから 8 時間以上水蒸気放出を持続させるために水に含浸 させた濾紙を 6 枚重补て設置した。水を用いるチャンバー試験におい ては、チャンバー内空気が飽和しないことや、湿度センサーの精度保 証上 $90 \% \mathrm{RH}$ を超えないよう、試験期間中適切な湿度範囲を維持する 必要がある。そのため、本試験では放散面積を調整し、試料負荷率 0.11 (建材放散試験では試料負荷率 2.2 を用いることが多い）に設定 した。

物質伝達率の算出にはチャンバー内空気の相対湿度を参照し $x_{a}=x_{\text {out }}$ とした。チャンバー内換気回数は 0.5 回 $/ \mathrm{h}(167 \mathrm{ml} / \mathrm{min})$ 、供給空気の 相対湿度 $20 \%$ RH に設定し $0.1 \%$ RH 単位で自動制御を行った。測定項 目としては供給空気の温湿度、チャンバー内空気の温湿度及び濾紙表 面の温度である。濾紙表面の相対湿度は飽和状態（100\%RH）と仮定 した。

\section{3 試験結果}

表 4 に気流速度に対する物質伝達率試験の結果を示す。また、JIS で説明する気流速度と物質伝達率（以下、JIS 值）の関係と試験值と の比較を図 5 に示寸。

湿度測定は 1 分間隔で、温度測定は 10 秒間隔で連続計測を行い、 算定にはチャンバー内水蒸気濃度が定常状態に到達し、安定した 8 時間〜9 時間の間の 1 時間分のデータを平均して用いた。供給空気の 相対湿度は設定值 $20 \% \mathrm{RH}$ に対し、測定值は平均 20.5\%RH であった。

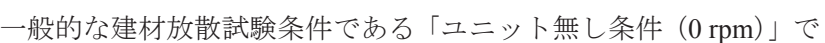
物質伝達率は $11.5 \mathrm{~m} / \mathrm{h}$ と、JIS A 1901 で推奨している物質伝達率 9 18m/h を満足する值となり、この条件で $4 \mathrm{~m} / \mathrm{h}$ 以下とする既往研究 結果より大きな值を示した。300～450 rpm（気流速度 $0.1 \mathrm{~m} / \mathrm{s}$ 以下）条 件において、JIS A 1905/1906 で推奨している $15 \pm 3 \mathrm{~m} / \mathrm{h}$ 範囲を満足す る結果となった。JIS 及び ISO ではこの物質伝達率範囲に相当する気 流速度を $0.25 \pm 0.05 \mathrm{~m} / \mathrm{s}$ と説明しているが、今回の試験ではより低い 気流速度でこの範囲となった。450〜 700 rpm (気流速度 $0.10 \sim 0.27 \mathrm{~m} / \mathrm{s}$ ) 条件において試験值は $17.4 \sim 22.0 \mathrm{~m} / \mathrm{h}$ 、試験值から算定した $0.3 \mathrm{~m} / \mathrm{s}$ 時 の物質伝達率は $22.4 \mathrm{~m} / \mathrm{h}$ となった。

今回の測定では試料負荷率が低かったことから、通常試験で用いら れている $\mathrm{L}=2.2$ 条件では物質伝達率が今回の試験より小さくなると 予想される。この点に関しては 6 項にて数值解析による検討を行う。

\section{6. 気流制御ユニットの数值流体解析}

20L 小型チャンバー内のユニットに装着した試料の表面付近の気 流速度、物質伝達率を測定した結果を基に CFD による数值解析を行 った。解析には STREAM ver. 7 （クレイドル社）を用いた。

\section{1 モデル概要}

図 6 にモデルの基本構成を、表 5 に解析条件を示す。シールボック ス部分を除く各部材の厚みは $1 \mathrm{~mm}$ 、解析領域は $20 \mathrm{~L}$ 小型チャンバー と同サイズとした。解析には層流モデルを用い、解析項目は流れ、熱、 絶対湿度とし、非定常解析を行った。

領域の側面下部から領域内に空気が流入し、チャンバー内の空気が 吸い込みファンによってユニット上部からユニット内に導入される。 ファンによる吐き出し気流でチャンバー内で繰り返し攪汼され、 0.5 回/hの換気分が領域上部の排気口から排出される。供給空気温度とチ ヤンバー内空気はともにチャンバー試験基準条件である $28^{\circ} \mathrm{C}$ 設定 した。制限条件としてチャンバー内相対湿度は $100 \%$ RH 以下とした。

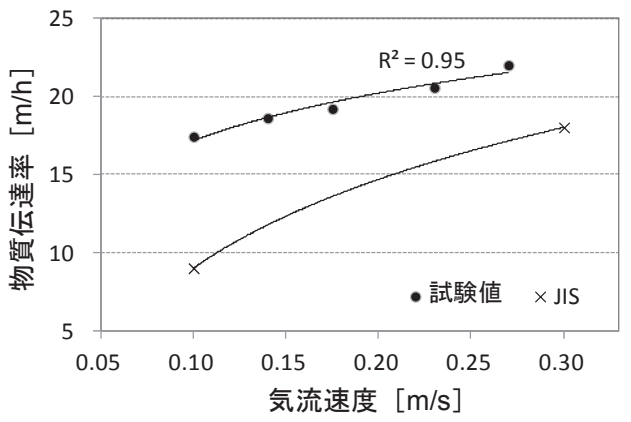

図 5 気流速度に対する物質伝達率試験の結果

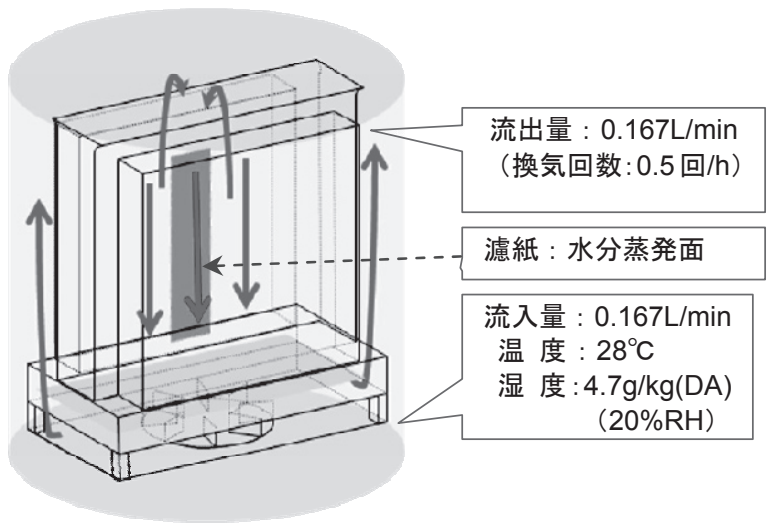

図 6 モデルの基本構成 
表5 CFD数值解析設定条件

\begin{tabular}{c|l|l}
\hline & \multicolumn{1}{|c|}{ 内 容 } & \multicolumn{1}{|c}{ 備 考 } \\
\hline 流れ解析 & 層流 & 非定常解析 \\
\hline 壁境界 & no-slip & \\
\hline 他の解析要素 & 温度、絶対湿度 & $\begin{array}{l}\text { 但し、 } 100 \% R H \text { 上限値とする } \\
\text { メッシュ分割 }\end{array}$ \\
\hline X, Y, Z: $5.0 \mathrm{~mm}$ & \\
\hline 解析サイクル & 30 秒 $\times 600$ サイクル \\
\hline 水蒸気拡散係数 & $2.56 \times 10^{-5}\left[\mathrm{~m}^{2} / \mathrm{s}\right]$ & \\
\hline 濾紙面湿度 & $24.0 \mathrm{~g} / \mathrm{kg}(\mathrm{DA})$ & \\
\hline 供給空気 & $167 \mathrm{ml} / \mathrm{min} 、 4.7 \mathrm{~g} / \mathrm{kg}(\mathrm{DA})$ & $28^{\circ} \mathrm{C} 、 100 \% \mathrm{RH}$ \\
\hline 熱境界 & 滤紙、排気口、給気口 & 熱伝導あり \\
\hline
\end{tabular}

\section{2 チャンバー内気流性状解析結果}

図 7 にユニット内及びチャンバー内気流性状解析結果を示す。また、 ユニット内解析結果には試料表面 $10 \mathrm{~mm}$ 離隔面上の 9 分割点における 気流速度分布を示した。ユニット内部及び建材表面付近に整流気流が 形成された。9 点の気流速度は $0.08 \sim 0.1 \mathrm{~m} / \mathrm{s}$ (平均 : $0.09 \mathrm{~m} / \mathrm{s} 、 \mathrm{RSD} \%$ : $8 \%$ ) であり、表面風速測定試験における $450 \mathrm{rpm}$ 条件 (平均: $0.1 \mathrm{~m} / \mathrm{s}$ 、 RSD\%：13\%）に近い気流性状が再現された。
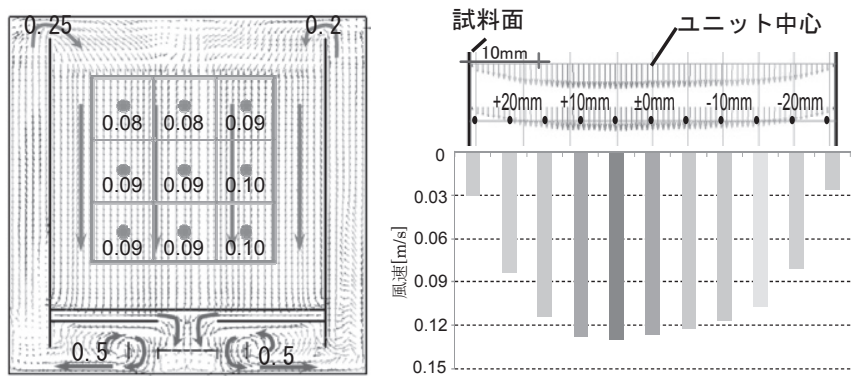

左図: 試料表面 $10 \mathrm{~mm}$ 地点における気流速度分布

右図：試料面からユニット中心までの気流速度分布

図 7 ユニット内及びチャンバー内気流性状

\section{3 物質伝達率算出結果}

表 6 に定常状態におけるチャンバー内湿度及び物質伝達率算出結 果を、図 8 亿試料負荷率と物質伝達率の関係を示す。

$\mathrm{L}=0.11$ 条件において $85 \% \mathrm{RH}(20.24 \mathrm{~g} / \mathrm{kg}(\mathrm{DA}))$ 、物質伝達率は $19.5 \mathrm{~m} / \mathrm{h}$ と試験值より $12 \%$ 高い結果となった。試験值の 550～600 rpm（気流速 度 $0.18 \sim 0.23 \mathrm{~m} / \mathrm{s}$ ) 条件に相当する值である。試料負荷率が大きくな るにつれ物質伝達率は漸減して $\mathrm{L}=0.44$ からはほぼ定常になり約 $15.3 \mathrm{~m} / \mathrm{h}$ に収束した。これは、限られた換気量に対して放散面積が増 加したことで、水蒸気飽和点 $(100 \% \mathrm{RH})$ に近づき、換気量によって 蒸発量が支配されるためと考えられる。

$\mathrm{L}=0.44 \sim 2.2$ 条件の物質伝達率平均（ $\mathrm{L}=0.44$ は片面解析值、他の条 件では両面解析結果值を用いた) は $15.3 \mathrm{~m} / \mathrm{h}$ で、 $\mathrm{L}=0.11$ 条件の $19.5 \mathrm{~m} / \mathrm{h}$ より $27 \%$ 、 $\mathrm{L}=0.22$ 条件の $16.0 \mathrm{~m} / \mathrm{h}$ よりは $5 \%$ 低い。 $\mathrm{L}=0.11$ 、気流速度 $0.1 \mathrm{~m} / \mathrm{s}(450 \mathrm{rpm})$ 条件の試験結果 $17.4 \mathrm{~m} / \mathrm{h}$ よりは $12 \%$ 低かった。

\section{7. 考察}

式 (4) 〜 (7) で求める理論值は試料面積に対する換気量比 $(\mathrm{Q} / \mathrm{A})$ の影響を受けないため試験值より高く算出されると予想されたが、 $\mathrm{L}=0.11$ 、気流速度 $0.1 \mathrm{~m} / \mathrm{s}$ 条件における試験值 $(17.4 \mathrm{~m} / \mathrm{h})$ や数值解析
結果 $(19.5 \mathrm{~m} / \mathrm{h})$ に比べて JIS 值 $(9.0 \mathrm{~m} / \mathrm{h})$ が低くなっている。境界層 型チャンバーと純水を用いた伊藤ら ${ }^{11)}$ の研究ではチャンバー中心位 置(試料表面から $30 \mathrm{~mm}$ 離隔) における気流速度 $0.1 \mathrm{~m} / \mathrm{s}$ 時に $15.7 \mathrm{~m} / \mathrm{h}$ 、 田中ら ${ }^{12}$ は水平型の気流制御ユニットと純水に含浸させた濾紙 （L=0.11）を用いた物質伝達率試験において、気流制御ユニット内風 速を約 $0.2 \mathrm{~m} / \mathrm{s}$ と推定された時に得られた物質伝達率を $15.2 \sim 16.0 \mathrm{~m} / \mathrm{h}$ と報告している。一方、本試験では $0.1 \mathrm{~m} / \mathrm{s}$ 気流下で $17.4 \mathrm{~m} / \mathrm{h} 、 0.2 \mathrm{~m} / \mathrm{s}$ で物質伝達率は $20.2 \mathrm{~m} / \mathrm{h}$ と算定され、いずれも既往研究より高い。本 研究との相違点は両既往研究ともに水平型の気流制御装置を用いた こと、伊藤らは液面を放散面として重量測定により放散量を測定した 点、田中らは含浸濾紙を放散材に用いたが気流速度の測定を行わず風 量から推定していたため試料表面付近の気流速度が明確ではない点 である。また、0.5 回/h 換気で気流制御を行わない条件において、村 上ら ${ }^{4)}$ の CFD による物質伝達率解析では $2 \sim 3 \mathrm{~m} / \mathrm{h}$ 、田辺ら ${ }^{6}$ の濾紙を 用いた物質伝達率試験では $3.1 \sim 4.7 \mathrm{~m} / \mathrm{h}$ （平均 $4.0 \mathrm{~m} / \mathrm{h}$ ) と報告してい る。本試験ではユニット無し条件で $11.5 \mathrm{~m} / \mathrm{h}$ と既往研究とは大きな

表 6 各試料負荷率条件における物質伝達率算出結果

\begin{tabular}{|c|c|c|c|c|}
\hline \multicolumn{2}{|c|}{$\begin{array}{c}\text { 試料負荷率 } \\
{\left[\mathrm{m}^{2} / \mathrm{m}^{3}\right]}\end{array}$} & $\begin{array}{c}\text { 絶対湿度 } \\
{[\mathrm{g} / \mathrm{kg}(\mathrm{DA})]}\end{array}$ & $\begin{array}{c}\text { 蒸発量 } \\
{[\mathrm{g} / \mathrm{h}]} \\
\end{array}$ & $\begin{array}{c}\text { 物質伝達率 } \\
{[\mathrm{m} / \mathrm{h}]}\end{array}$ \\
\hline 0.055 & 片面 & $18.83(79 \% \mathrm{RH})$ & 0.161 & 25.8 \\
\hline 0.11 & 片面 & $20.24(85 \% \mathrm{RH})$ & 0.177 & 19.5 \\
\hline 0.22 & 片面 & $21.52(90 \% \mathrm{RH})$ & 0.191 & 16.0 \\
\hline 0.44 & 片面 & $22.64(94 \% \mathrm{RH})$ & 0.203 & 15.5 \\
\hline \multirow{2}{*}{0.73} & 片面 & $23.16(96 \% \mathrm{RH})$ & 0.209 & 14.8 \\
\hline & 両面 & $23.20(96 \% \mathrm{RH})$ & 0.209 & 15.5 \\
\hline \multirow{2}{*}{0.88} & 片面 & $23.26(97 \% \mathrm{RH})$ & 0.210 & 14.8 \\
\hline & 両面 & $23.30(97 \% \mathrm{RH})$ & 0.210 & 15.6 \\
\hline \multirow{2}{*}{1.10} & 片面 & $23.37(97 \% \mathrm{RH})$ & 0.211 & 13.4 \\
\hline & 両面 & $23.42(97 \% \mathrm{RH})$ & 0.212 & 14.4 \\
\hline 1.76 & 両面 & $23.64(98 \% \mathrm{RH})$ & 0.214 & 15.4 \\
\hline 2.20 & 両面 & $23.73(99 \% \mathrm{RH})$ & 0.215 & 15.5 \\
\hline
\end{tabular}

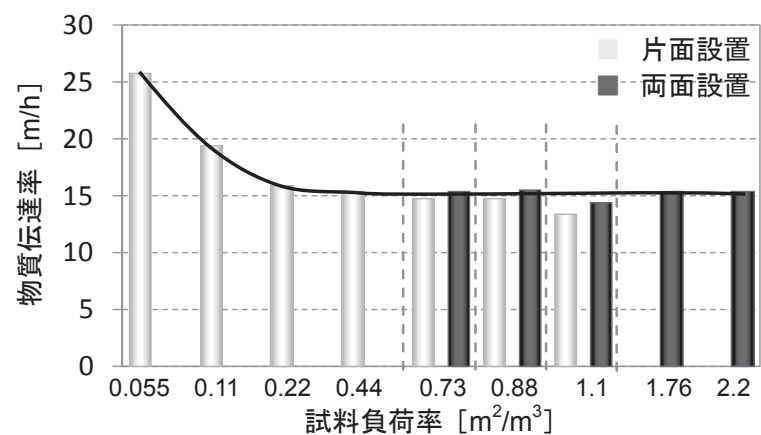

図 8 試料負荷率と物質伝達率の関係

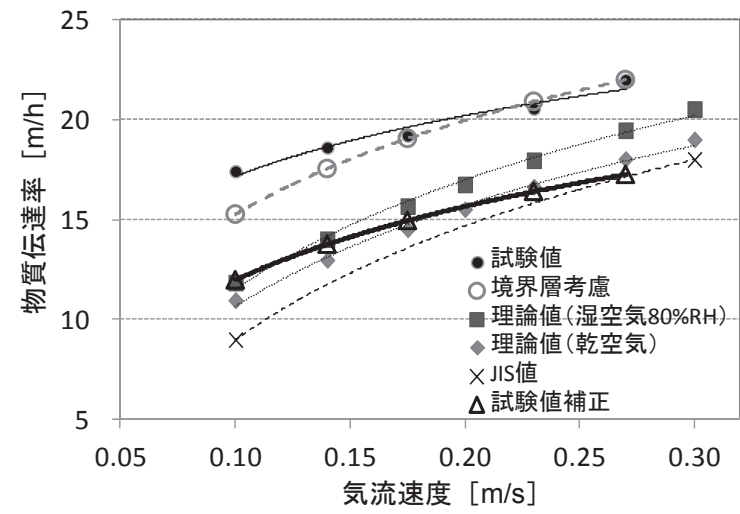

図 9 気流速度と物質伝達率の関係 
差が出ている。また、数值解析結果でも $0.1 \mathrm{~m} / \mathrm{s}$ 条件で $15.3 \mathrm{~m} / \mathrm{h}$ に収束 し、JIS 值 $9 \mathrm{~m} / \mathrm{h}$ より高い值になる。これらの結果から、ユニット無 し条件でも今まで提案されてきた $\lceil 4 \mathrm{~m} / \mathrm{h}$ 以下」よりは高いことが考 えられた。

そこで、試験結果に基づき、気流速度に対する物質伝達率を理論式 （4）〜（7）により推定した。チャンバー内空気温度 $29^{\circ} \mathrm{C} 、$ 動粘性 係数は乾き空気及び $80 \% \mathrm{RH}$ 湿り空気の物性值 ${ }^{16)}$ 注 2 )を用い、代表長 さを試料長さ $0.147 \mathrm{~m}$ とした。試験值、JIS 值と共に $29^{\circ} \mathrm{C}$ 条件で乾き 空気と湿り空気の物性值から求めた理論值を図 9 に示した。境界層考 慮とは気流速度測定位置 $10 \mathrm{~mm}$ が速度境界層内に存在する場合、代表 気流速度から考える物質伝達率より大きく測定されることから、試験 時の気流速度を代表気流速度と見なして推定した值である。後述する が、気流速度 $0.19 \mathrm{~m} / \mathrm{s}$ 以下では境界層内速度となるため理論值曲線か ら得られた回帰式を用いて $0.19 \mathrm{~m} / \mathrm{s}$ 以下を代表気流速度と見なして試 験值を再推定した。また、境界層及び試料負荷率を考慮して試験值か ら再推定したものを試験值補正として図 9 にプロットした。これは $\mathrm{CFD}$ 解析結果、 $\mathrm{L}=0.11$ 条件は $\mathrm{L}=0.44$ 以上より物質伝達率が $27 \%$ 大き くなったことから境界層考慮值にその誤差率を適用したものである。

濾紙表面からの水蒸気発生は周辺空気が飽和に近づけば、両者間の 絶対湿度差は小さくなる（式（2）。そそのため、小型チャンバーのよ うに限られた容積と換気量下では空気中湿度が高くなり温湿度の小 さな測定誤差でも物質伝達率に与える影響が大きくなる。精度の高い 測定を行うには、チャンバー内湿度をなるべく低く維持することが重 要である。数值解析から $\mathrm{L}=0.44$ 以上で定常值に近い結果が得られて いるため、試験の際にも $\mathrm{L}=0.44$ 以上を用いることが望ましいが、 $\mathrm{L}=0.22$ でも大きな差はない結果となっている。但し、今回は供給空 気の相対湿度 $20 \% \mathrm{RH}$ と低い条件で試験を行ったが、 $\mathrm{L}=0.11$ でもチャ ンバー内空気の相対湿度 70〜 $80 \% \mathrm{RH}$ を計測したためより高い湿度の 空気を利用する場合は飽和に注意する必要がある。

表 6 と図 8 で示寸数值解析による試料負荷率と物質伝達率との関係 で片面設置と両面設置に差が生じた。同じ試料負荷率であれば放散面 を2 分割して両側に設置した方が物質伝達効率が高くなる。解析から は $\mathrm{L}=0.73 \sim 1.1$ で両面設置条件の物質伝達率が $5 \sim 8 \%$ 高く、放散面積 が大きくなるにつれ設置方法の影響も大きくなった。チャンバー内で 充分な混合が行われる前の空気が再度放散面付近に供給されている ことが原因である。建材放散試験の際には気流制御ユニットを使用せ ず試験を行うのが一般的であり、空気はチャンバー内をゆっくりと循 環するため、このような不均一混合が生じる可能性を排除できない。 但し、殆どの放散試験が $\mathrm{L}=2.2$ の両面設置条件で行われているため、 物質濃度の偏りの影響は少なくなると考えられる。

Lewisの関係 ${ }^{17)}$ 注3) から、0.1 $\mathrm{m} / \mathrm{s} \sim 0.27 \mathrm{~m} / \mathrm{s}$ 条件における物質伝達率

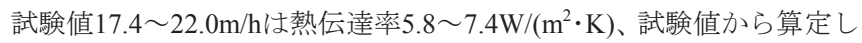
た $0.3 \mathrm{~m} / \mathrm{s}$ 時の物質伝達率 $22.4 \mathrm{~m} / \mathrm{h} / 27.5 \mathrm{~W} /\left(\mathrm{m}^{2} \cdot \mathrm{K}\right)$ となり、一般的な室内 表面における熱伝達率 $2 \sim 7 \mathrm{w} /\left(\mathrm{m}^{2} \cdot \mathrm{K}\right)$ に近い值であり、空気温度 $29^{\circ} \mathrm{C} \cdot$ $80 \%$ RH 湿り空気の平面上層流による理論対流熱伝達率 2.9 $4.7 \mathrm{~W} /\left(\mathrm{m}^{2} \cdot \mathrm{K}\right)$ よりは多少高い值であった。ユニット無し (0rpm) 条件 の物質伝達率試験值 $11.5 \mathrm{~m} / \mathrm{h}$ （熱伝達率換算 $3.9 \mathrm{~W} /\left(\mathrm{m}^{2} \cdot \mathrm{K}\right)$ ) は、垂直平 面の自然対流における $\left.2.2 \mathrm{~W} /\left(\mathrm{m}^{2} \cdot \mathrm{K}\right)\right)^{18)}$ より多少大きいが、既往のCFD 解析から予測されてきた物質伝達率 $4 \mathrm{~m} / \mathrm{h}$ 以下、熱伝達率 $1.4 \mathrm{~W} /\left(\mathrm{m}^{2} \cdot \mathrm{K}\right)$ より大きい。ファンが設置されていないチャンバー内は 0.5 回 $/ \mathrm{h} の$ 換気
が行われても強制対流とは見なせない微弱な気流形成であると仮定 すると自然対流分が主に作用する。特に水平ではなく垂直に設置され た滤紙面での蒸発冷却による温度低下は濾紙周辺にドラフトを生じ させ、物質伝達を促進する要因となることが試験值が大きくなる原因 の一つと考えられる。無論、数值流体解析でも濾紙表面温度が空気温 度と同じと仮定すると表面温度が高くなる分蒸発量も増加する。 $0.1 \mathrm{~m} / \mathrm{s}$ 条件の試験結果を参照すると、空気温度 $29^{\circ} \mathrm{C}$ で濾紙表面温度 $1.5^{\circ} \mathrm{C}$ 低下条件と両者等温条件で物質伝達率を等しくなるためには等 温条件における水分蒸発量は非等温条件 $\left(1.5^{\circ} \mathrm{C}\right.$ 差) の蒸発量の約 1.6 倍にならなければならない。

他には空気の動粘性係数が考えられる。乾き空気と $80 \% \mathrm{RH}$ の湿り 空気の動粘性係数は約 $60 \%$ 違うため、式（4）〜（7）を用いて算出 する物質伝達率は 7〜 8\%程度乾き空気の方が小さくなる。

図 9 で回帰曲線は「試験值」が「理論值及び JIS 值」とは異なる傾 向を示しており、試験值は気流速度の増加による物質伝達率の増加が 理論值より緩やかである。気流速度 $0.1 \sim 0.3 \mathrm{~m} / \mathrm{s}$ で物質伝達率理論值 は $80 \% \mathrm{RH}$ 湿り空気 $11.8 \sim 20.5 \mathrm{~m} / \mathrm{h}$ 、乾き空気 $11.0 \sim 19.0 \mathrm{~m} / \mathrm{h}$ と JIS 值 より若干大きくなったが、試験值はこれらより依然と高い。この時、 湿り空気による速度境界層厚さ $(99 \%){ }^{177}$ は試料中間地点で $14 \mathrm{~mm}$ $8 \mathrm{~mm}$ 、試料終端で $19 \sim 11 \mathrm{~mm}$ 程度となり、試料中間で表面上 $10 \mathrm{~mm}$ 地点が境界層内となる代表気流速度は約 $0.19 \mathrm{~m} / \mathrm{s}$ である。つまり、試 料表面から $10 \mathrm{~mm}$ 地点における気流速度測定值 $0.19 \mathrm{~m} / \mathrm{s}$ 以下は境界層 内の值となり、図 9 でも $0.2 \mathrm{~m} / \mathrm{s}$ を境にこれによるものと考えられる 試験值と理論值との差が開き、 $0.1 \mathrm{~m} / \mathrm{s}$ では試験值が理論值より $47 \%$ 大きいが $0.27 \mathrm{~m} / \mathrm{s}$ では $13 \%$ 大きいだけで境界層の影響が小さくなった ことで差も縮まると考えられる。試験值から境界層内気流速度ではな く代表気流速度 $0.1 \mathrm{~m} / \mathrm{s}$ に対する物質伝達率を理論值との相関から推 定すると $15.3 \mathrm{~m} / \mathrm{h}$ となる（図 9 の凡例「境界層考慮」）。境界層を考慮 しても JIS の 9m/h、Zhang ら 9.7 10.7m/h、理論值 $11.8 \mathrm{~m} / \mathrm{h}$ よりは大 きい。ISO16000-9 では試料表面から $10 \mathrm{~mm}$ 離隔した地点で気流速度 を測定するようにしているが、これは $0.19 \mathrm{~m} / \mathrm{s}$ 以下では測定点が速度 境界層内に入ってしまうため代表気流速度とは言えず、代表気流速度 $0.1 \sim 0.3 \mathrm{~m} / \mathrm{s}$ に対応させた物質伝達率 $9 \sim 18 \mathrm{~m} / \mathrm{h}$ は低風速域で整合しな いことに注意しなければならない。

上述内容から、境界層及び試料負荷率を考慮して試験值から再推定 すると（図 9 の「試験值補正」）、0.1 0.3 $/ \mathrm{s}$ における物質伝達率は $12.0 \sim 17.5 \mathrm{~m} / \mathrm{h}$ と JIS 值より低風速域では多少高いが、気流速度の増 加と共に同等な值となった。

\section{8. まとめ}

本研究では小型チャンバーにおける気流速度及び試料負荷率と物 質伝達率との関係を調べた。小型チャンバー内の物質伝達率を制御す るための気流制御ユニットを開発し、ユニットの気流制御性能測定実 験として試料表面付近における気流速度及び気流分布測定を行った。 蒸留水を用いた物質伝達率試験では試料負荷率 $\mathrm{L}=0.11$ に固定し気流 速度を変化させた。更に、数值解析を通じて試料負荷率と物質伝達率 との関係を調べた。その結果を以下に䌂める。

1) 気流制御ユニットのファン回転数と試料表面付近の気流速度に正 の直線による相関が得られ、回転数 $450 \sim 725 \mathrm{rpm}$ で気流速度 0.1 $0.3 \mathrm{~m} / \mathrm{s}$ と算定された。試料表面上における気流速度分布の偏差が少な 
く整流に近い気流が形成された。

2) 物質伝達率試験の結果、気流速度 $0.10 \sim 0.27 \mathrm{~m} / \mathrm{s}$ 条件において試験 值は $17.4 \sim 22.0 \mathrm{~m} / \mathrm{h}(0.3 \mathrm{~m} / \mathrm{s}$ では $22.4 \mathrm{~m} / \mathrm{h}$ と算定 $)$ となった。「ユニッ 卜無し条件」における物質伝達率試験值は $11.5 \mathrm{~m} / \mathrm{h}$ で、気流速度 $0.1 \mathrm{~m} / \mathrm{s}$ 以下でも、JIS A 1905/1906 で推奨している $15 \pm 3 \mathrm{~m} / \mathrm{h}$ 範囲を満足 し、JIS 值及び理論值より高い結果となった。

3) $\mathrm{L}=0.11$ の同じ試料負荷率条件下で物質伝達率は数值解析值、試験 值、理論值の順に低くなった。

4) 数值解析結果 $\mathrm{L}=0.44$ 以上で定常に等しい值となり、 $\mathrm{L}=0.44 \sim 2.2$ 条件の物質伝達率平均は $15.3 \mathrm{~m} / \mathrm{h}$ であった。 $\mathrm{L}=0.22$ で $16 \mathrm{~m} / \mathrm{h}$ と定常平 均值との差は $5 \% 、 \mathrm{~L}=0.11$ では $19.5 \mathrm{~m} / \mathrm{h}$ と $27 \%$ の差があった。試料負 荷率 $\mathrm{L}=0.11$ を用いると飽和のおそれが少なく試験が容易になるが、 試料負荷率が低いため通常チャンバー試験における物質伝達率との 差が大きく、補正が必要である。一方、 $\mathrm{L}=0.22$ を用いると飽和の心 配も少ない上、物質伝達率の定常值との差も小さくなる結果となった。 5) 数值解析結果、試料の両面設置が片面設置より物質伝達率が5 $8 \%$ 増加した。

6) 気流速度 $0.1 \mathrm{~m} / \mathrm{s} \sim 0.27 \mathrm{~m} / \mathrm{s}$ における物質伝達率試験值 $17.4 \sim 22.0 \mathrm{~m} / \mathrm{h}$

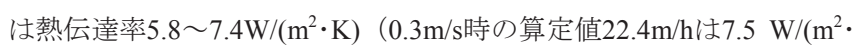
$\mathrm{K})$ ) と一般的な室内表面における熱伝達率 $2 \sim 7 \mathrm{w} /\left(\mathrm{m}^{2} \cdot \mathrm{K}\right)$ に近い值とな った。また、ユニット無し条件の $11.5 \mathrm{~m} / \mathrm{h}$ 、熱伝達率 $3.9 \mathrm{~W} /\left(\mathrm{m}^{2} \cdot \mathrm{K}\right)$ は、 既往研究の物質伝達率 $4 \mathrm{~m} / \mathrm{h}$ 以下、熱伝達率 $1.4 \mathrm{~W} /\left(\mathrm{m}^{2} \cdot \mathrm{K}\right)$ 上り大きな值 を示した。

7) 気流速度測定值 $0.19 \mathrm{~m} / \mathrm{s}$ 以下では境界層厚が $10 \mathrm{~mm}$ 以上であるため、 低風速になるほど物質伝達率の試験值と理論值との差が大きくなる。 そのため、ISO16000-9で定義する試料表面から10mm離隔した地点で の気流速度 $0.1 \sim 0.3 \mathrm{~m} / \mathrm{s}$ と JIS で定める代表気流速度 $0.1 \sim 0.3 \mathrm{~m} / \mathrm{s}$ におけ る物質伝達率は $0.1 \sim 0.19 \mathrm{~m} / \mathrm{s}$ の低風速域で整合しなくなる。

8) 低風速域では気流速度測定点が境界層内に入ることと試験試料負 荷率が小さかったことを考慮して再推定した結果、気流速度 0.1 $0.3 \mathrm{~m} / \mathrm{s}$ における物質伝達率は $12.0 \sim 17.5 \mathrm{~m} / \mathrm{h}$ となり、理論值及びJIS值に 近い值となった。

9) ISOで示す気流速度条件はJISで定める物質伝達率範囲を満足する ことができるが、JISの物質伝達率は低風速域ではISOの気流速度に整 合しない結果となった。また、本試験で使用した20L程度の小型チャ ンバーのように換気量が少なく狭小空間で空気循環がある場合は一 般的なチャンバー試験条件下で物質伝達率評価試験を行うのは難し い。実際のチャンバー試験より求めることができるよう試験条件を明 確にした上で物質伝達率を提案する必要がある。

\section{謝辞}

この研究成果は、早稲田大学理工学研究所の「12L20-室内空気質と 熱的快適性に関寸る研究」の成果の一部である。本研究を行うにあた り、鹿島建設株式会社持田恵吾様 (元早稲田大学大学院創造理工学研 究科修士課程）、（有）ADTEC有賀隆男様、有賀淳也様、元（有） ADTEC横溝透修様には多大なご協力とご助言を頂きました。記して 深く謝意を表します。

注

注1）言葉として小型チャンバーが一般的であるが、JIS規格では「小形」と表 記していることから、JIS規格名を言及寸る際のみ「小形」を使用した。
注2）空気温度 $29^{\circ} \mathrm{C} 、 80 \% \mathrm{RH}$ 湿り空気に対して、動粘性係数 $1.011 \times 10^{-5} \mathrm{~m}^{2} / \mathrm{s}$ 、熱 伝導率 $0.01951 \mathrm{~W} /(\mathrm{m} \cdot \mathrm{K})$ 、比熱 $1042.6 \mathrm{~J} /(\mathrm{kg} \cdot \mathrm{K})$ 、乾き空気の動粘性係数は $1.615 \times 10^{-5} \mathrm{~m}^{2} / \mathrm{s}$ を用いた。

注3）温度が均一な板を対象とした強制対流による熱伝達率は以下の式により 求めた。また、Lewis数は1と仮定した。

$h_{c}=\frac{N u \times \lambda}{l}, \quad N u=0.664 \times R e^{1 / 2} \times \operatorname{Pr}^{1 / 3}, \operatorname{Pr}=\frac{v \times \rho \times C_{p}}{\lambda}, \quad L e=\frac{h_{c}}{k_{c} \times \rho \times C_{p}}$

Le : Lewis 数 $[-]$

$R e$ : レイノルズ数 $[-]$

hc ： 対流熱伝達率 $\left[\mathrm{W} /\left(\mathrm{m}^{2} \cdot \mathrm{K}\right)\right]$

$\mathrm{Cp} ：$ 比熱 $[\mathrm{J} /(\mathrm{kg} \cdot \mathrm{K})]$

$v$ : 動粘性係数 $\left[\mathrm{m}^{2} / \mathrm{h}\right]$

$\mathrm{Nu} \quad$ ： ヌッセルト数 [-]

$\operatorname{Pr} \quad:$ プラントル数 [-]

$k_{c} \quad$ : 物質伝達率 $[\mathrm{m} / \mathrm{h}]$

$l \quad:$ 代表長さ $[\mathrm{m}]$

: 流体密度 $\left[\mathrm{kg} / \mathrm{m}^{3}\right]$

\section{参考文献}

1) 村上周三、田辺新一：JIS使い方シリーズ シックハウス対策に役立つ小形 チャンバー法解説［JIS A 1901］、日本規格協会、2003

2) 日本機械学会：伝熱工学資料 改訂第4版、日本機械学会、pp.42-49、 pp.114-117、1986

3) ISO 16000-9: Determination of the emission of volatile organic compounds from building products and furnishing - Emission test chamber method, 2006

4) 村上周三、加藤信介、朱清宇、田辺新一、伊藤一秀: 揮発性有機化合物の 放散・吸脱着等のモデリングとその数值予測に関する研究 (その27)小型チ ヤンバーADPAC内の物質放散性状に関寸るCFD解析, 日本建築学会大会 学術講演梗概集 D-II、pp.811-812、2001.09

5) 舟木理香、田辺新一、田中博 : 建材からのアルデヒド類・VOC放散速度測 定用小型チャンバーの性能試験及び異なるチャンバー間におけるホルム アルデヒド放散量の比較、日本建築学会環境系論文集、第572号、pp.47-54、 2003.10

6) 田辺新一、伴野正幸、舟木理香、田中博 : 小型チャンバーADPACを用いた アルデヒド類、VOC放散量の測定に関する研究 その3 小型チャンバー ADPAC内の物質伝達率に関寸る考察, 日本建築学会大会学術講演梗概集, D-II、pp.819-820、2001.09

7) JIS A 1905 : 小形チャンバー法による室内空気污染濃度低隇材の低減性能試 験法一第1 部 : 一定ホルムアルデヒド濃度供給法による吸着速度測定一、 一第2部：ホルムアルデヒド放散建材を用いた吸着速度測定一、2007.02

8) JIS A 1906 : 小形チャンバー法による室内空気污染濃度低減材の一定揮発性 有機化合物（VOC）、ホルムアルデヒドを除く他のカルボニル化合物濃度 供給法による吸着速度試験、2008.02

9) 安宅勇二、加藤信介、伊藤一秀、朱清宇、村上周三 : 化学反応型パッシブ 吸建材の浱度低減効果に関する研究 濃度低減効果測定法の開発と検証 第1報、日本建築学会環境系論文集、第581号、pp.59-64、2004.07

10) 朱清宇、加藤信介、村上周三、伊藤一秀 : 境界層型小型Test Chamberの開 発と試験建材表面の化学物質伝達率に関する実験とCFD解析、日本建築学 会環境系論文集、第549号、pp.45-66、2001.11

11）伊藤一秀、村上周三、加藤信介、近藤靖史、朱清宇、神卓也 : 揮発性有機 化合物の放散・吸脱着等のモデリングとその数值予測に関する研究（その 14）建材表面気流精密制御Small Test Chamberの開発と物質伝達率の測定、 空気調和・衛生工学会学術講演会講演論文集、pp.493-496、1999.09

12）田中博、木原生雄、中川貴文、舟木理香、田辺新一: 小型チャンバーADPAC を用いたアルデヒド類、VOC放散量の測定に関する研究その10 気流制御 ユニット内の物質伝達率測定、日本建築学会大会学術講演梗概集 D-II、 pp.933-934、2003.09

13) Y. Zhang and F.Haghighat : A small air velocity-controlled test chamber for emission studies, Characterizing sources of indoor air pollution and related sink effects, ASTM STP 1287, pp.23-33, 1996

14）持田恵吾、金勲、田中祐輔、有賀隆男、田辺新一：小型チャンバーADPAC を用いたアルデヒド類、VOC放散量の測定に関する研究 その16 新型気 流制御ユニットの開発、日本建築学会大会学術講演梗概集 D-II、pp.957-958、 2008.08

15) 持田恵吾、金勲、有賀隆男、田辺新一: 小型チャンバーADPACを用いたア ルデヒド類、VOC放散量の測定に関する研究 その18 新型気流制御ユニ ットの物質伝達性能試験、日本建築学会大会学術講演梗概集 D-II、 pp.877-878、2009.08

16) C.Richard Tracy, William R.Welch, Warren P.Porter : Properties of air - A manual for use in biophysical ecology third edition - , University of Wisconsin, 1980

17) 空気調和・衛生工学会: 空気調和・衛生工学便覧 第13版-1 基礎編、 p. $216-219 、$ pp.164-166、2001.11

18) 木村建一: 建築設備基䃈理論演習、学献社、p.51、1970.07 